\title{
THE INFLUENCE OF SODIUM CHLORIDE AND WATERLOGGING STRESSES ON ALNUS CORDATA
}

\author{
by Glynn C. Percival, Martin P. Biggs, and Geoffrey R. Dixon
}

\begin{abstract}
Sodium chloride solutions were applied as a root drench to containerized Alnus cordata trees grown in freely drained or waterlogged compost substrates. Leaf chlorophyll fluorescence; cell' electrolyte leakage; plant mortality; leaf necrosis; time to bud burst; and leaf, shoot, and root macronutrient concentrations were evaluated. Waterlogging using distilled water caused no significant stress compared to controls, apart from increasing root iron and manganese concentrations. Complete mortality was recorded in trees watered with a sodium chloride solution $\geq 4.5 \%$ or waterlogged in sodium chloride solutions $\geq 2 \%$. Watering or waterlogging with distilled water had no significant effect on mortality, while $66.6 \%$ of trees watered with a $2 \%$ sodium chloride solution died. Applications of sodium chloride tended to increase time to bud burst compared to controls. Irrespective of whether trees were grown in freely drained or waterlogged compost, applications of sodium chloride to roots decreased leaf chlorophyll fluorescence and increased cell electrolyte leakage and leaf necrosis for up to 15 days after bud burst. Significant reductions in chlorophyll fluorescence was detected by day 3 following bud burst; however, significant increases in cell electrolyte leakage and leaf necrosis were not detected until day 6 . Applications of sodium chloride significantly increased sodium and chloride concentrations in root, leaf, and shoots irrespective of drainage, with higher concentrations reflecting applications of stronger salt solutions. Calcium, phosphorous, magnesium, and potassium concentrations in cell tissues were unaffected by treatments. Depressed leaf and shoot copper, zinc, and iron concentrations were recorded in trees waterlogged in sodium chloride solutions $\geq 4.5 \%$. Irrespective of treatment, no significant effects on manganese concentrations of leaf and shoot tissue were found, but significantly lower concentrations of manganese were recorded in roots. Greater reductions generally reflected stronger applications of sodium chloride.
\end{abstract}

The environmental, sociological, recreational, and psychological benefits of growing trees in urban environments are now widely recognised, resulting in more than $100,000,000$ trees planted in such areas throughout Britain (Bradshaw 1981). Trees planted in urban landscapes such as streets, public recreation areas, and car parks are selected primarily for their aesthetic qualities (Percival and Hitchmough 1995). Consequently, very little information is available about their tolerance to environmental stresses faced in such environments (drought, waterlogging, deicing salts). This lack of knowledge results in the deaths of hundreds of thousands of trees on a annual basis due to inappropriate species or site selection.

Deicing salts are directly responsible for the deaths of more than 700,000 trees annually in Western Europe alone (Dobson 1991). With increases in traffic volume and the expansion of road networks throughout the United Kingdom, the quantity of salt used for deicing operations has increased correspondingly. In many environments, conditions may be modified to suit particular tree species by manipulating root zone qualities (i.e., increasing or decreasing $\mathrm{pH}$ ). However, in urban areas where conditions are more static, this is not always possible or feasible. Research should focus on the selection of trees possessing aesthetic and functional design qualities that may not be currently planted in urban environments, but which possess superior stress resistance.

Italian alder was selected for the present study because of its landscape qualities. Alnus are pioneer species that rapidly colonize open fields or barren areas following gravel or coal extraction. This species achieves rapid growth in cold, waterlogged situations, indicating biological tolerance to hostile urban conditions (Ware 1994). In a survey of 3,600 trees in towns throughout England, $A$. cordata was present on only 24 occasions, yet only 6 other tree species produced higher mean shoot extension (Hodge 1991). Previous experimentation has demonstrated that A.cordata is highly tolerant of salt (NaCl) sprays (Percival and Dixon 1997). Whether a similar response occurs when $\mathrm{NaCl}$ is applied to root systems was unknown.

In the current research, treatments (salt $x$ waterlogging) were applied singly and in combination during dormancy. Although information is available concerning the influence of single environmental stresses on trees, single-stress 
studies fail to reflect the multiplicity of abiotic stress interactions that trees experience. As a result, tree species that perform well under arbitrary experimental conditions fail to perform well when planted in situ where a range of stresses are encountered. Similarly, experimentation is generally performed during periods of active growth and rarely during the winter when trees are dormant. Results from experiments performed during active growth may not reflect those obtained from plants during dormancy (Dobson 1991). Indeed, little data are available to determine how stress applied during dormancy affects subsequent growth and development. Objectives of the current study were to evaluate $A$. cordata for use in urban environments and to explore its physiological attributes in response to individual and combined stresses caused by salinity and waterlogging applied during dormancy.

\section{Materials and Methods}

Plant material. The experiment used 4-year-old Italian alder, 1.5 to $1.7 \mathrm{~m}$ high, which had been grown for 2 years in a seed bed and then transferred into plastic pots $(26 \mathrm{~cm}$ diameter by $23 \mathrm{~cm}$ deep) filled with compost. The soil was loamy in texture ( $24 \%$ clay, $45 \%$ silt, $31 \%$ sand), $3.1 \%$ organic carbon, $\mathrm{pH} 6.6$, and supplemented with the controlled release nitrogen-based fertilizer Enmag (Salisbury House, Weyside Park, Goldmar, Surrey, UK) at a rate of $1 \mathrm{~g} / \mathrm{kg}$ compost. The experiment started 6 weeks after leaf fall, when trees were deemed to be dormant, on January 19, 1996 (week 0). Trees were placed in an unheated transparent polyethylene tunnel at the Department of Horticulture, SAC Auchincruive, Ayr, Scotland, continuing until March 1 (week 6). Thereafter the trees were placed under glass and flushed with tap water to remove excess salt that may have accumulated in the compost. Growing conditions under glass were $22^{\circ} \mathrm{C} \pm 2^{\circ} \mathrm{C}\left(71.6^{\circ} \mathrm{F} \pm\right.$ $35.6^{\circ} \mathrm{F}$ ) supplemented with $400-\mathrm{W}$ high-pressure sodium lamps (SON/T) providing a photoperiod of $16 \mathrm{~h}$ light and $8 \mathrm{~h}$ dark and $250 \mu \mathrm{mol} \mathrm{m} \mathrm{m}^{-2} \mathrm{~s}^{-1}$ photosynthetically active radiation (PAR) at the tree crown. The experimental design used was a completely randomised block with 12 replications per treatment.
During the 6-week period in the tunnel, the treatments were 1) distilled water, $2 \%, 4.5 \%$, and $7 \%$ sodium chloride solutions applied as weekly drenches to trees growing in freely drained compost until solutions were observed emerging from drainage holes; and 2) waterlogging in distilled water, $2 \%, 4.5 \%$, and $7 \%$ sodium chloride solutions for the 6 weeks' duration. In the case of treatment no. 1 , the compost water content was adjusted daily to maintain it between $75 \%$ and $100 \%$ of pot capacity by weighing the freely drained pots and flushing with tap water to prevent salt accumulation in the compost. Waterlogging was performed by placing the 26-cm-diameter pots inside larger 28-cm-deep plastic buckets and flooding until $2 \mathrm{~cm}$ of water overlaid the compost surface. This depth was maintained by inspecting daily and watering when necessary. Trees growing in freely drained pots and drenched with distilled water were used as controls. During the 6-week period, the minimum and maximum air temperatures were $-16.2^{\circ} \mathrm{C}$ and $8.4^{\circ} \mathrm{C}\left(2.8^{\circ} \mathrm{F}\right.$ to $\left.47.1^{\circ} \mathrm{F}\right)$, respectively, while minimum and maximum daily relative humidity varied between $24.3 \%$ and $64.6 \%$. Irradiance was measured daily at $1300 \mathrm{~h}$ using infrared gas analysis and averaged $139 \mu \mathrm{mol} / \mathrm{m}^{2} / \mathrm{s}$ PAR. All pots were widely spaced, thereby reducing competition for light.

Analytical techniques: Bud burst. The time to bud burst following treatments (i.e., from March 1 onwards), defined as green leaves emerging from the scales (Cannell and Smith 1983), was recorded visually.

Chlorophyll fluorescence. Before measurements, leaves were dark adapted for $40 \mathrm{~min}$ by attaching light exclusion clips to leaf surfaces in situ. Chlorophyll fluorescence measurements were obtained with a portable fluorescence spectrometer (Hansatech Instruments Ltd, Kings' Lynn, UK). Eight leaves were randomly selected per tree and each leaf tagged, ensuring that measurements came from the same leaf throughout the experiment. Readings were obtained at 3-day intervals at $1300 \mathrm{~h}$ until day 15 . In all cases, chlorophyll fluorescence measurements refer to the $\mathrm{Fm} / \mathrm{Fv}$ ratios, which represent the maximum quantum yield of Photosystem II, which in turn is 
Table 1. Effects of sodium chloride applications on nutrient concentrations in roots of $\boldsymbol{A}$. cordata. Analysis was based on samples collected 15 days after bud burst. Means are based on 12 replications.

\begin{tabular}{|c|c|c|c|c|c|c|}
\hline \multirow[b]{2}{*}{ Treatment } & \multicolumn{6}{|c|}{ Nutrient concentration ( $\mathrm{g} / \mathrm{kg}$ dry weight) } \\
\hline & $\mathrm{Na}$ & $\mathrm{Cl}$ & $\mathrm{Cu}$ & $\mathrm{Zn}$ & $\mathrm{Fe}$ & $\mathrm{Mn}$ \\
\hline \multicolumn{7}{|c|}{ Freely drained compost ${ }^{z}$} \\
\hline Distilled water & $1.13^{\mathrm{y}} \mathrm{a}$ & $1.48 \mathrm{a}$ & 16.10ab & $62.03 \mathrm{ab}$ & $1886 a$ & $255.54 c$ \\
\hline $2 \% \mathrm{NaCl}$ & $5.77 \mathrm{~b}$ & $5.39 b$ & $19.50 \mathrm{~b}$ & $67.62 b$ & $1667 a$ & $109.08 b$ \\
\hline $4.5 \% \mathrm{NaCl}$ & $19.34 \mathrm{e}$ & $62.34 \mathrm{C}$ & $18.20 \mathrm{ab}$ & $69.10 b$ & $1802 a$ & $101.36 b$ \\
\hline $7 \% \mathrm{NaCl}$ & $29.99 f$ & $82.90 d$ & $17.20 \mathrm{ab}$ & $55.14 a$ & $1778 a$ & $63.34 \mathrm{a}$ \\
\hline \multicolumn{7}{|c|}{ Waterlogging with salt solutions } \\
\hline Distilled water & $1.27 \mathrm{a}$ & $1.37 \mathrm{a}$ & $15.43 a b$ & $67.49 b$ & $2910 b$ & $343.17 d$ \\
\hline $2 \% \mathrm{NaCl}$ & $6.31 b$ & $6.90 b$ & $14.80 \mathrm{a}$ & $66.84 b$ & $1582 \mathrm{a}$ & $87.62 a$ \\
\hline $4.5 \% \mathrm{NaCl}$ & $10.11 \mathrm{c}$ & $89.30 e$ & $15.00 \mathrm{a}$ & $69.81 b$ & $1490 a$ & $64.68 \mathrm{a}$ \\
\hline $7 \% \mathrm{NaCl}$ & $14.60 d$ & $133.00 f$ & $15.10 \mathrm{a}$ & $56.94 a$ & $1797 a$ & $68.50 a$ \\
\hline
\end{tabular}

${ }^{2}$ Trees growing in freely drained compost watered with distilled water were used as controls

yMeans separated using Fisher's Protected LSD at $P=0.05$. Means with the same letter are not significantly different.

$\mathrm{Na}=$ sodium; $\mathrm{Cl}=$ chloride; $\mathrm{Cu}=$ copper; $\mathrm{Zn}=$ zinc; $\mathrm{Fe}=$ iron; $\mathrm{Mn}=$ manganese .

highly correlated to the quantum yield of net photosynthesis-providing a rapid quantitative measurement to determine plant response to stress (Demmig and Bjorkman 1987; BolharNordenkampf et al. 1989; Adams et al. 1995).

Leaf necrosis. Assessments of sodium chloride and waterlogging damage to leaves were estimated visually on a 1 to 6 scale $(0=$ no necrosis; $1=<1 \%$ necrosis; $2=1-10 \%$ necrosis; $3=10-25 \%$ necrosis; $4=25-50 \%$ necrosis; $5=$ $50-75 \%$ necrosis; $6=>75 \%$ necrosis). Assessments were made at 3-day intervals until day 15 .

Cell electrolyte leakage. At 3, 6, 9, 12, and 15 days after bud burst, quantitative damage to leaf cell tissue was assessed by measuring electrolyte leakage. Leaves were excised and placed in $30 \mathrm{~mL}$ Universal bottles containing $20 \mathrm{~mL}$ distilled water. Samples were stored at $22^{\circ} \mathrm{C}$ for $24 \mathrm{~h}$ in darkness before conductivity measurements were taken with a Jenway conductivity probe and M4070 meter (BDH, Loughborough, UK). Total solute leakage was obtained by autoclaving for $1 \mathrm{~h}$ at $121^{\circ} \mathrm{C}\left(249.8^{\circ} \mathrm{F}\right)$ and $0.103 \mathrm{MPa}$. Results are presented as percentage of solute leakage after $24 \mathrm{~h}$.

Inductively coupled plasma-emission spectroscopy (ICP) elemental analysis. Root, shoot, and leaf samples were thoroughly washed, then dried in a convection oven at $85^{\circ} \mathrm{C}$ for $48 \mathrm{~h}$ before grinding through a $0.5 \mathrm{~mm}$ cyclone mill (Retsch, Middlesborough, UK). Samples (0.5 g) were placed into $150 \mathrm{~mL}$ volumetric flasks and digested in $20 \mathrm{~mL}$ of $7: 1$ nitric/perchloric acid. After cooling, the solutions were brought to volume with deionized water and analysed by ICP. Nutrient values were expressed as $\mathrm{g} / \mathrm{kg}$ dry weight.

Statistical analysis. Treatment effects were determined by analysis of variance (ANOVA) using the Genstat 5 program (Lawes Agricultural Trust 1990). Differences among treatment means were separated by the least significance difference (LSD) at the 0.05 level of probability.

\section{Results}

For all parameters assessed, trees grown in compost waterlogged with distilled water did not significantly alter from controls, with the exception of significantly higher $(P>0.01)$ root concentrations of iron and manganese (Table 1). Following applications of sodium chloride to tree roots in both waterlogged and freely drained compost, maximal reductions in chlorophyll fluorescence $(\mathrm{Fm} / \mathrm{Fv}=0.00)$, leaf necrosis $(100 \%)$, and cell electrolyte leakage ( $80 \%$ to $98 \%$ ) were detected by day 15 following bud burst (Figures 1, 2, and 3). Consequently, all trees were harvested and nutrient concentrations analysed. 
Time to bud burst. Applications of sodium chloride at higher concentrations tended to increase time to bud burst. These effects, however, were not significant compared to controls. Mean bud burst ranged from 57.2 to 68 days for trees in freely drained substrates and from 57.7 to 70 days in waterlogged compost.

Mortality. By day 15 after bud burst, all trees watered with sodium chloride solutions $\geq 4.5 \%$ or waterlogged in sodium chloride solutions $\geq 2 \%$ were dead. Watering or waterlogging with distilled water resulted in no mortality, while $2 / 3$ of trees watered with a $2 \% \mathrm{NaCl}$ solution died.

Chlorophyll fluorescence, cell electrolyte leakage, leaf necrosis. Irrespective of whether trees were grown in freely drained soil or waterlogged in salt-amended solutions, exposure of the roots to sodium and chloride ions decreased leaf chlorophyll fluorescence (Figure 1) and increased cell electrolyte leakage (Figure 2) and leaf necrosis (Figure 3 ), from days 0 to 15 . Significant reductions in chlorophyll fluorescence were de- tected by day $3(P<0.05)$, with significant increases in cell electrolyte leakage and leaf necrosis occurring by day 6 . The greatest severity of effects on chlorophyll fluorescence, cell electrolyte leakage, and leaf necrosis resulted from drenching trees grown in freely drained compost with $4.5 \%, 7 \%$, and $7 \% \mathrm{NaCl}$, respectively $(P<$ 0.01 ).

Root and shoot macronutrient concentrations. Applications of sodium chloride significantly increased $(P<0.01)$ sodium and chloride concentrations in root (Table 1) and shoot tissue (Table 2) of trees grown in freely drained soil or waterlogged in salt-amended solutions. Higher root and shoot sodium and chloride concentrations reflected applications of stronger $\mathrm{NaCl}$ solutions.

Greater amounts of sodium were found in the shoots of trees waterlogged in a $7 \% \mathrm{NaCl}$ solution and in the roots of trees watered with a $7 \%$ $\mathrm{NaCl}$ solution grown in freely drained compost, respectively. Maximal concentrations of chloride were recorded in the shoots of trees watered with

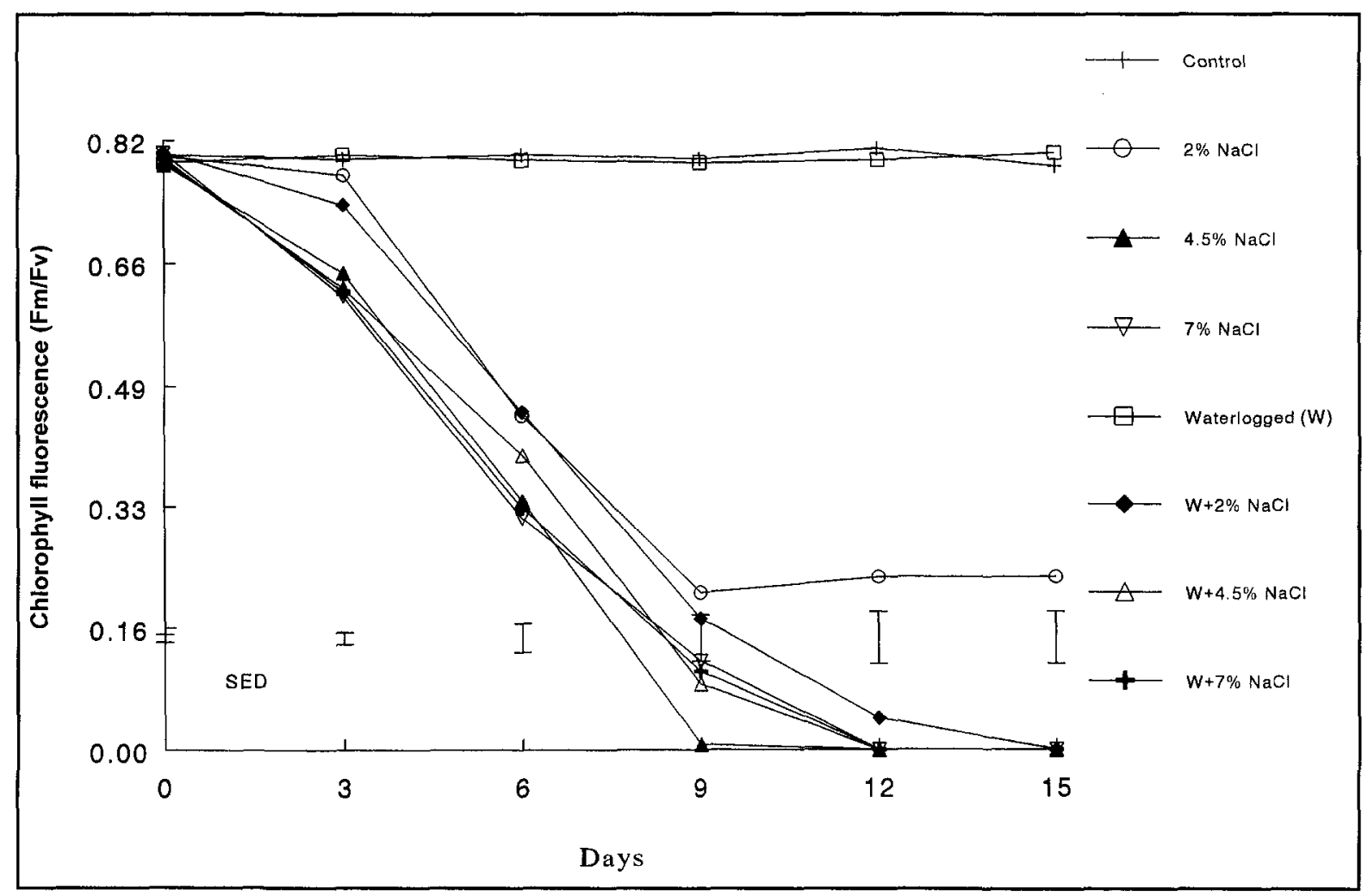

Figure 1. Chlorophyll fluorescence of $A$. cordata following application of $\mathrm{NaCl}$ to the root system. 


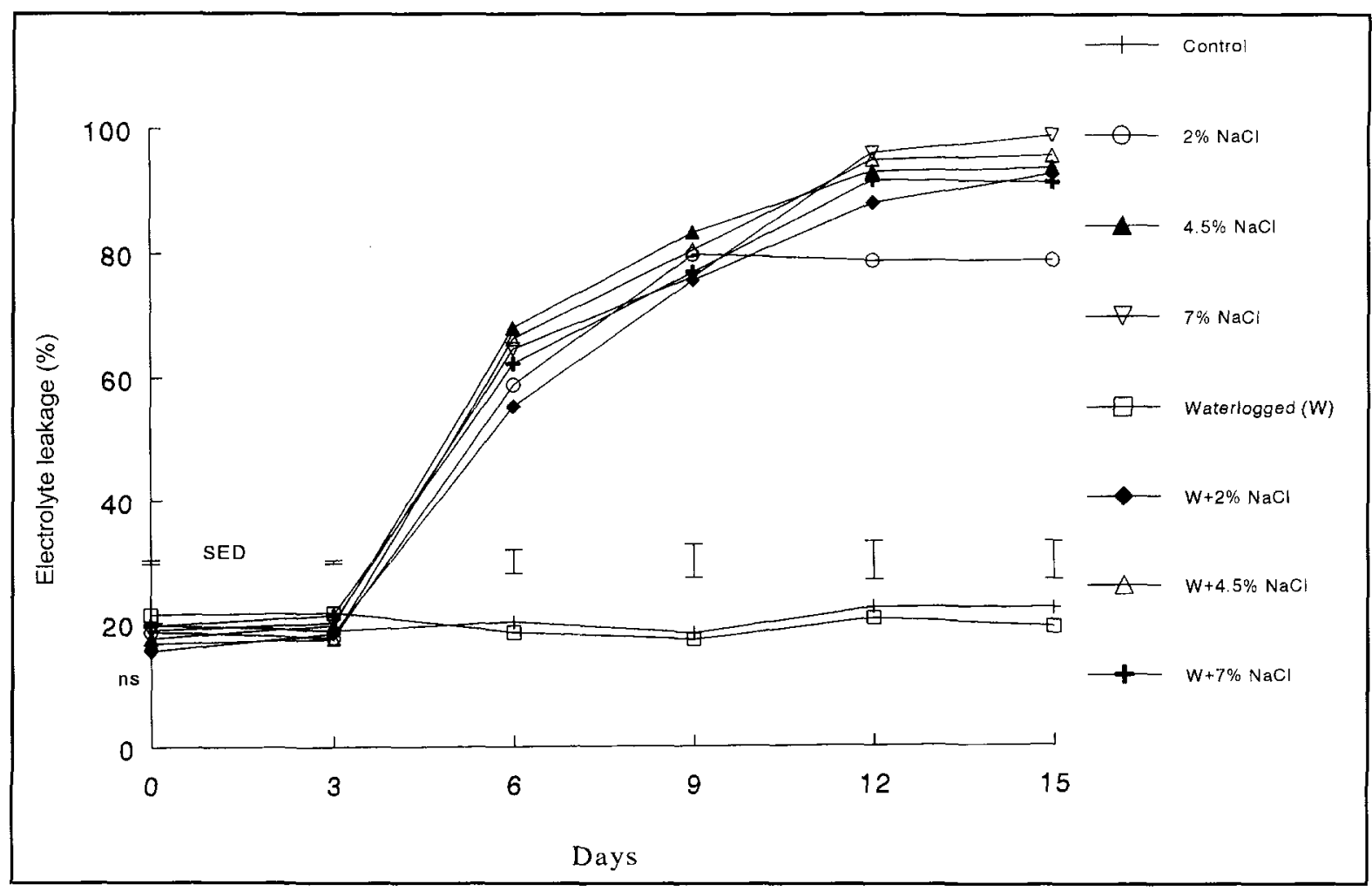

Figure 2. Electrolyte leakage of $\boldsymbol{A}$. cordata following application to the root system.

a $7 \% \mathrm{NaCl}$ and in roots of trees waterlogged in a $7 \% \mathrm{NaCl}$ solution, respectively. Minimal foliar and root concentrations of each element were apparent in trees not subjected to salinity.

No treatment effects upon shoot and root calcium, phosphorous, magnesium, and potassium concentrations were identified (data not shown). Irrespective of treatment, no significant effects upon copper concentrations in root tissue were recorded. Significantly reduced concentrations ( $P$ $<0.01$ ) of copper were, however, recorded in shoot tissue with greater reductions reflected by stronger $\mathrm{NaCl}$ applications. Shoot concentrations of zinc and iron were significantly lower $(P<0.05)$ in trees waterlogged in $\mathrm{NaCl}$ solutions $\geq 4.5 \%$ only. Irrespective of treatment, no significant effects upon manganese concentrations in shoot tissue were recorded. Significantly reduced concentrations $(P<0.01)$ of manganese were, however, recorded in roots with greater reductions generally reflected by stronger $\mathrm{NaCl}$ applications.

\section{Discussion}

Applications of sodium chloride to roots resulted in high mortality rates by day 15 after bud burst. These results highlight the importance of a more rigorous approach to quantifying salt tolerance of species through the use of $\mathrm{NaCl}$ applications to both foliage and roots. Previous experimentation demonstrated $A$. cordata to be highly tolerant to foliar salt spray even under waterlogged conditions (Percival and Dixon 1997). Similar phenomena have been recorded with Acer platanoides, which was classified as salt tolerant by Lumis et al. (1973) and Sucoff (1975) but as salt sensitive by Schiechtl (1978) and Kreutzer (1977), Similarly, Thuja occidentalis was reported as tolerant of salt applied to roots but sensitive to foliar salts (Lumis et al. 1973; Sucoff 1975), and Juglans nigra is reported to be sensitive to salt in the soil but reasonably tolerant of sprays (Monke and Weibe 1961; Monk and Peterson 1962; Leh 1975). 


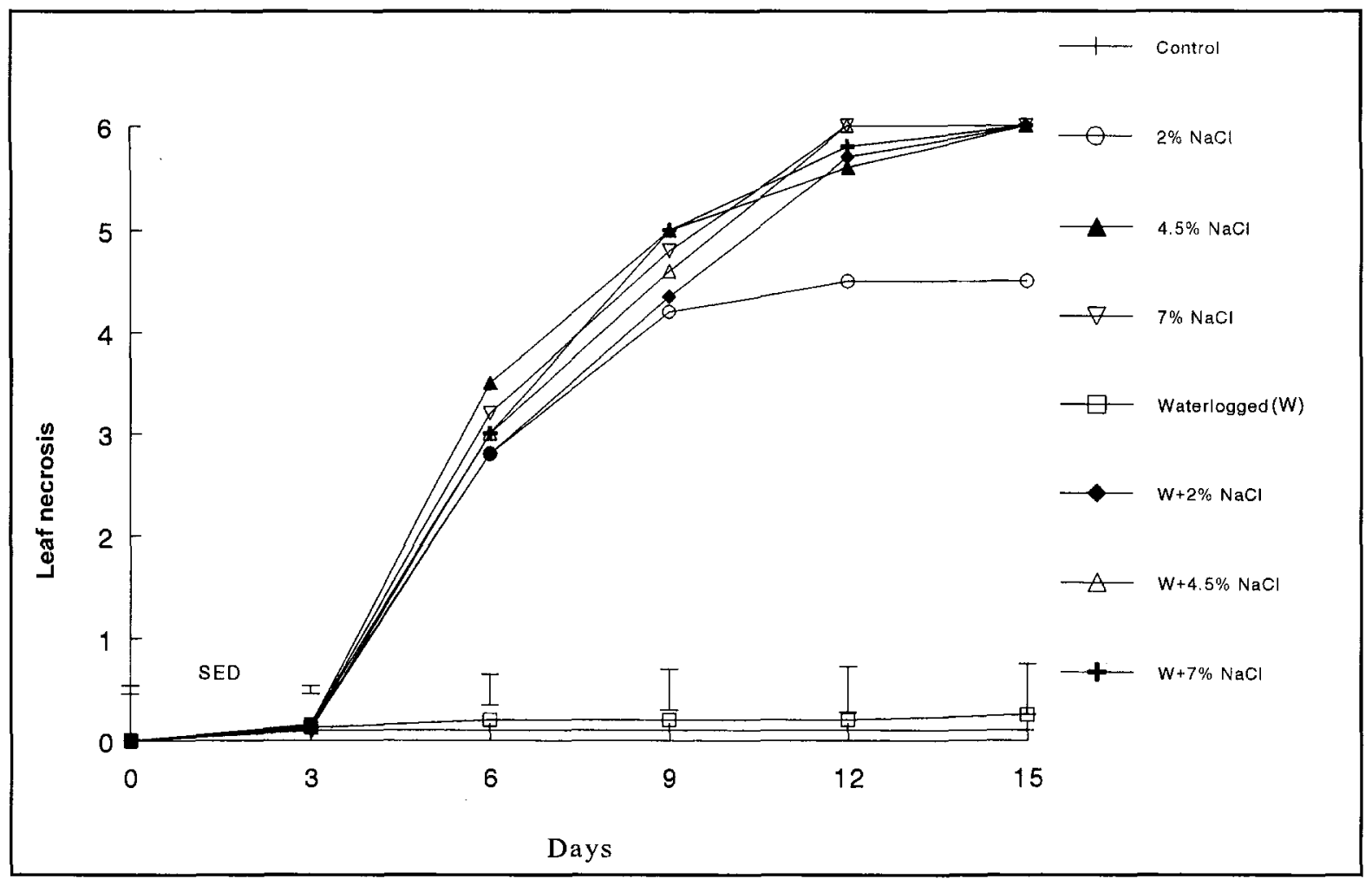

Figure 3. Leaf necrosis of $A$. cordata following application of $\mathrm{NaCl}$ to the root system.

Table 2. Effects of sodium chloride applications on nutrient concentrations in shoots (leaves and stems) of $A$. cordata. Analysis was based on samples collected 15 days after bud burst. Means are based on 12 replications.

\begin{tabular}{|c|c|c|c|c|c|c|}
\hline \multirow[b]{2}{*}{ Treatment } & \multicolumn{6}{|c|}{ Nutrient concentration ( $\mathrm{g} / \mathrm{kg}$ dry weight) } \\
\hline & $\mathrm{Na}$ & $\mathrm{Cl}$ & $\mathrm{Cu}$ & $\mathrm{Zn}$ & $\mathrm{Fe}$ & $\mathrm{Mn}$ \\
\hline \multicolumn{7}{|c|}{ Freely drained compost ${ }^{z}$} \\
\hline Distilled water & 0.26 ya & $2.78 \mathrm{a}$ & $7.55 \mathrm{c}$ & $50.05 b c$ & $136.25 b c$ & $>525.00 \mathrm{a}$ \\
\hline $2 \% \mathrm{NaCl}$ & $13.00 \mathrm{~b}$ & $16.10 \mathrm{~b}$ & $8.47 c$ & $48.74 b c$ & $127.01 b$ & $>525.00 \mathrm{a}$ \\
\hline $4.5 \% \mathrm{NaCl}$ & $42.20 c$ & $45.00 c$ & $8.14 \mathrm{c}$ & $52.43 c$ & $128.87 b$ & $>525.00 \mathrm{a}$ \\
\hline $7 \% \mathrm{NaCl}$ & $46.58 d$ & $59.00 d$ & $3.10 \mathrm{ab}$ & $53.16 \mathrm{c}$ & $150.56 \mathrm{c}$ & $>525.00 \mathrm{a}$ \\
\hline \multicolumn{7}{|c|}{ Waterlogging with salt solutions } \\
\hline Distilled water & $0.63 a$ & $3.07 a$ & $7.08 \mathrm{c}$ & $49.37 \mathrm{bc}$ & $138.94 b c$ & $>525.00 \mathrm{a}$ \\
\hline $2 \% \mathrm{NaCl}$ & $13.24 b$ & $21.46 b$ & $4.70 b$ & 41.33ab & $128.65 b$ & $490.03 a$ \\
\hline $4.5 \% \mathrm{NaCl}$ & $40.22 c$ & $44.10 \mathrm{c}$ & $2.39 a$ & $34.57 a$ & $68.22 \mathrm{a}$ & $>525.00 \mathrm{a}$ \\
\hline $7 \% \mathrm{NaCl}$ & $53.05 e$ & $46.40 \mathrm{c}$ & $2.41 a$ & $34.17 \mathrm{a}$ & $52.16 a$ & $524.59 a$ \\
\hline
\end{tabular}

${ }^{2}$ Trees growing in freely drained compost watered with distilled water were used as controls y Means separated using Fisher's Protected LSD at $P=0.05$. Means with the same letter are not significantly different. $\mathrm{Na}=$ sodium $; \mathrm{Cl}=$ chloride $; \mathrm{Cu}=$ copper $\mathrm{Zn}=$ zinc $; \mathrm{Fe}=$ iron; $\mathrm{Mn}=$ manganese . 
Data for a range of trees (Dobson 1991) suggest that salt toxicity resulting in visual leaf necrosis develops at chlorine contents greater than $1 \%$ oven dry weight for broadleaves and circa $0.5 \%$ for conifers. There are few reports that correlate such treatments with tree death. Because $2 / 3$ of trees watered with a $2 \%$ sodium chloride solution in this investigation died, the tolerance threshold for sodium and chloride ions in roots and shoots of $A$. cordata was 5.77 and 5.39, and 13.0 and $16.1 \mathrm{~g} / \mathrm{kg}$ dry weight, respectively.

Regardless of drainage, applications of sodium and chloride ions to roots decreased leaf chlorophyll fluorescence and increased cell electrolyte leakage and leaf necrosis from days 3 and 6 , respectively. Chlorophyll fluorescence identifies stress injury before it becomes visible and thus provides a rapid method for screening plants in breeding programmes (Greaves and Wilson 1987). The technique has been used to evaluate responses of crop species to detrimental influences such as freezing, salinity, and drought. It can provide rapid quantitative assessment with which to rank species depending on their sensitivity. Chlorophyll fluorescence may also have implications for arboriculturists (Percival and Dixon 1997). Although established techniques are available to detect tree decline due to biotic causes, there are few that detect abiotic stress in situ. Early detection of stress, before obvious physical deterioration, may allow effective remedial action. However, it is debatable whether detection of stress by chlorophyll fluorescence would occur early enough for remedial action to be effective. Results do highlight a potential use of chlorophyll fluorescence as a diagnostic system for the utility industry with which to detect stress in trees (Percival and Dixon 1997).

Sodium and chloride ions influence the uptake and internal distribution of other nutrients. Results elsewhere suggest that they decrease the levels of tissue calcium, magnesium, potassium, and phosphorous (Stavarek and Rains 1983). Other studies indicate that waterlogging alone reduced the uptake and transport of nitrogen, phosphorous, potassium, calcium, and iron (Mclean 1993). Townsend (1984), however, demonstrated that essential elements present in stem and leaf tissue of 6 tree species increased in response to applications of sodium chloride. Few studies have analysed the combined effects of salinity and waterlogging on uptake and translocation of nutrients (Farrell et al. 1996).

Results presented here demonstrate an increase in the root concentration of iron and manganese for trees waterlogged with distilled water only. An adaptation to waterlogging involves the internal transport of oxygen within the plant. Oxygen is absorbed by aerial tissue and translocated via the phloem to the roots. There it diffuses into the rhizosphere, preventing an accumulation of toxic compounds such as hydrogen sulphide (Kozlowski et al. 1991). Trees reported to possess this ability include Populus x petrowskiana, Salix alba, S.fragilis, and S.atrocinereal (Kozlowski et al. 1991). Following this adaptation, the roots became coated by minerals (Fisher and Stone 1991), primarily iron and manganese oxides (Ding and Musgrave 1995). Results indicated such a metabolic adaptation in response to waterlogging by $A$. cordata. An increase in these elements was not observed, however, in the presence of sodium and chloride ions. Indeed iron, manganese copper, and zinc concentrations were, on occasion, reduced compared to controls, suggesting salt inhibited such a metabolic adaptation.

\section{Conclusions}

Damage caused by deicing salts and waterlogging is a serious but frequently underestimated problem that affects substantial numbers of roadside plantings worldwide. Further research is now required to select trees with superior tolerance to such stresses linked to desirable street tree characteristics. Quantification of stress tolerance must employ a holistic approach, considering combinations of stress interactions likely to be encountered in the urban environment to provide more informative data of tolerance levels. Previous research showed high tolerance to foliar applied $\mathrm{NaCl}$ indicating $A$. cordata an ideal species for exposed coastal planting (Percival and Dixon 1997). Current work shows $A$. cordata to be sensitive to soil-applied $\mathrm{NaCl}$ and consequently, it could not be recommended for planting along 
roadsides, particularly when planted into clay soils prone to waterlogging.

Acknowledgements. The authors gratefully acknowledge the support, in part, by a grant from the International Society of Arboriculture Research Trust. SAC are partially funded by the Scottish Office Agriculture Environment and Fisheries Department (SOAEFD; ROAMES No. 648706). Expert technical assistance by $L$. Baird is gratefully acknowledged.

\section{Literature Cited}

Adams III, W.W., B. Demmig-Adams, A.S. Verhoeven, and D.H. Barker. 1995. Photoinhibition during winter stress: Involvement of sustained xanthophyll cycle dependent energy dissipation. Austr. J. Plant Physiol. 22:261-276.

Bolhar-Nordenkampf, H.R., S.P. Long, N.R. Baker, G. Oquist, U. Schreiber, and E.G. Lechner. 1989. Chlorophyll fluorescence as a probe of the photosynthetic competence of leaves in the field: $A$ review of current instrumentation. Func. Ecol. 3:497-514.

Bradshaw, A.D. 1981. Arboriculture: The research need. In Research for Practical Arboriculture. S. Hodge (Ed.) J. For. Comm. Bull. 97.

Cannell, M.G.R., and R.I. Smith. 1983. Thermal time, chill days and prediction of budburst in Picea sitchensis. J. Appl. Ecol. 20:951-963.

Demmig, B., and O. Bjorkman. 1987. Comparison of the effect of excessive light on chlorophyll fluorescence (77K) and photon yield of 02 evolution in leaves of higher plants. Planta 171:171-184.

Ding, N., and M.E. Musgrave. 1995. Relationship between mineral coating on roots and yield performance of wheat under waterlogging stress. J. Exp. Bot. 46:939-945.

Dobson, M.C. 1991. Deicing salt damage to trees and shrubs. For. Comm. Bull. 101.

Farrell, R.C.C., D.T. Bell, K. Akilan, and J.K. Marshall. 1996. Morphological and physiological comparisons of clonal lines of Eucalyptus camaldulensis. II. Responses to waterlogging/ salinity and alkalinity. Aust. J. Plant Physiol. 23:509-518.

Fisher, H.M., and E.L. Stone. 1991. Iron oxidation at the surfaces of slash pine roots from saturated soils. J. Soil Sci. Soc. Am. 55:1123-1129.

Greaves, J.A., and J.M. Wilson. 1987. Chlorophyll fluorescence analysis-an aid to plant breeders. Biologist 34(4):209-214.
Hodge, S.J. 1991. Urban Trees: A survey of street trees in England. For. Comm. Bull. 99, HMSO London.

Kozlowski, T.T., P.J. Kramer, and S.G. Pallardy. 1991. The Physiological Ecology of Woody Plants. Academic Press, San Diego, CA/

Kreutzer, K. 1977. Effects of deicing salts on roadside forests. Forstwiss. Centralbl. 96:76-83.

Lawes Agricultural Trust .1990. Genstat 5 Committee of the Statistics Dept., AFRC Institute of Arable Crops Research, Rothamsted Experimental Station, Harpenden, Hertfordshire, UK. Publ. NAG.

Leh, H.O. 1975. The damage to street trees from salt used for thawing ice. Dtsche. Baumsch. 27:250253.

Lumis, G.P., G. Hofstra, and R. Hall. 1973. Sensitivity of roadside trees and shrubs to aerial drift of deicing salts. HortScience. 9:475-477.

Lumis, G.P., G. Hofstra, G., and R. Hall. 1976. Salt damage to roadside plants. J. Arboric. 1:14-16.

Mclean, S. 1993. An investigation into the tolerance of seven species of street tree to soil deoxygenation. Bachelor of Horticultural Science Thesis. VCAH Burnley, Melbourne, Australia.

Monk, R.W. and H.B. Peterson. 1962. Tolerance of some trees and shrubs to saline conditions. In Proceedings of the American Society for Horticultural Science. 81:556-561.

Monk, R.W., and H.H. Wiebe. 1961. Salt tolerance and protoplasmic salt hardiness of various woody and herbaceous ornamental plants. Plant Physiol. 36:478-482.

Percival, G.C., and G.R. Dixon. 1997. Detection of salt and waterlogging stress in Alnus cordata by measurement of leaf chlorophyll fluorescence. J. Arboric. 23:181-190.

Percival, G.C., and J. Hitchmough. 1995. Tree establishment and performance in a cool growing season arboretum. Arboric. J. 19(4): 357-371.

Schiechtl, H.M. 1978. New conclusions to the question of resistance of woody plants to thawing salts. Garten und Landschaft. 4:24-245.

Stavarek, S.J., and D.W. Rains. 1983. Mechanisms for salinity tolerance in plants. lowa State J. Res. 57:457-476.

Sucoff, E. 1975. Effects of deicing salts on woody plants along Minnesota roads. Minn. Agric. Exp.Sta. Tech. Bull. 303.

Townsend, A.M. 1984. Effect of sodium chloride on tree seedlings in two potting media. Environ. Pollut. (series A) 34:333-344.

Ware, G.H. 1994. Ecological bases for selecting urban trees. J. Arboric. 20(3):98-103. 


\author{
Department of Horticulture \\ SAC Auchincruive \\ Ayr, KA6 5HW \\ Scotland \\ UK
}

Résumé. L'influence de solutions de chlorure de sodium a été étudiée à la fois sur des Alnus cordata empotés avec un compost à forte ou à faible rétention en eau; les solutions étaient appliquées en mouillant les racines afin d'observer les effets sur la prolifération en chlorophylle foliaire, la perte en électrolytes cellulaires, la mortalité de la plante, la création de nécroses foliaires, la période de bourgeonnement ainsi que les concentrations en macroéléments dans les feuilles, les pousses et les racines. L'imprégnation avec de l'eau distillée n'a causé aucun stress significatif comparativement avec les sujets-contrôle, à part des concentrations plus élevées en fer et en manganèse dans les racines. Une mortalité complète était enregistrée lorsque les arbres étaient arrosés avec une solution de chlorure de sodium $\geq 4,5 \%$ ou imprégnés d'eau avec des solutions $\geq 2 \%$. Arroser ou imprégner avec de l'eau distillée n'avait aucun effet tandis qu'une mortalité s'élevant à $66,6 \%$ était notée chez les arbres arrosés avec une solution de chlorure de sodium à $2 \%$. Les applications de chlorure de sodium ont allongé la période d'éclosion des bourgeons par rapport aux arbres-contrôle. Peu importe que les arbres soient cultivés dans un compost à fort ou à faible rétention en eau, les applications de chlorure de sodium sur les racines ont fait diminuer la floraison de chlorophylle foliaire et fait augmenter la perte d'électrolytes cellulaires ainsi que la nécrose foliaire jusqu'à 15 jours après l'éclosion des bourgeons. Les applications de chlorure de sodium ont fait augmenter significativement les concentrations en sodium et en chlore dans les racines, les feuilles et les pousses sans regard avec le drainage, et ce avec des concentrations plus élevées, reflétant ainsi des applications de solutions salines plus fortes. Aucun effet causé par ces traitements n'a été détecté par rapport aux concentrations en calcium, phosphore, magnésium et potassium dans les racines, les feuilles et les pousses. Des concentrations plus faibles en cuivre, zinc et fer dans les feuilles et les pousses ont été notées chez les arbres imprégnés avec des solutions de chlorure de sodium $\geq 4,5 \%$. Peu importe le traitement, aucun effet significatif n'a été observé sur le manganèse racinaire. Généralement, plus les applications de chlorure de sodium étaient fortes, plus les réductions étaient prononcées. 